\title{
The Scientific Information Manual The Kuybyshev Reservoir ${ }^{1}$
}

\author{
N. M. Mineeva
}

DOI: $10.1134 / \mathrm{S} 1995082909020138$

Since the impoundment of the Volga River reservoirs, a massive body of data obtained during observations of all the ecosystem components has been accumulated. However, these materials are scattered and it is hard to collect and systematize the data if necessary. It is also difficult to obtain reference information from governmental organizations dealing with monitoring natural objects, because this kind of information is expensive. Under these conditions, the scientific information manual The Kuybyshev Reservoir, edited by G.S. Rozenberg and L.A. Vykhristyuk, is of great scientific interest and practical value. This manual was published by the Institute of the Ecology of the Volga Basin, Russian Academy of Sciences. International experience in preparing informational publications concerning intercontinental waterbodies was used to compile the manual. One such example is the Survey of the State of World Lakes published in five volumes in Japan in the 1990s within the framework of the United Nations Environment Programme (UNEP) and the International Lake Environment Committee (ILEC). However, this publication is hardly accessible for the wide range of readers.

This manual includes information accumulated over the half century period of studies on Europe's largest flat man-made lake, the Kuybyshev Reservoir. It is based on the long-term archived and published data of monitoring studies carried out by the Kuybyshev Biological Station of the Institute for Biology of Inland Waters; the USSR Academy of Sciences (1957-1985);

\footnotetext{
${ }^{1}$ The Kuybyshev Reservoir (A Scientific Information Manual). Tolyatti: Institute of the Ecology of the Volga Basin, Russian Academy of Sciences, 2008.
}

the Institute of Ecology of Volga Basin, Russian Academy of Sciences (1989-1994); the Samara Hydrometeorological Service, including the branch of the Tolyatti Specialized Hydrometeorological Observatory (1989, 1993, 1991, and 2001-2005); and other scientific institutions that conducted studies in the reservoir. The information is presented in the form of 120 tables and 46 graphs reflecting the seasonal, interannual, and spatial dynamics of elements of the reservoir ecosystem. The list of references consists of 188 publications.

In brief, the book contains data on the history of the reservoir's creation, the physical-geographic conditions of the water catchment area, and the hydrochemistry of the water and bottom sediments. Data on the anthropogenic load and contents of pollutants are given too. Considerable attention is paid to the hydrobiological indices: the number, biomass, and production of aquatic organisms (aquatic fungi, protists, bacterio-, phyto-, and zooplankton, zoobenthos); the composition of the fish community, and the spread of invasive species. An assessment of the ecological state of the man-made lake, including the trophic state and water quality as assessed by chemical and biological indices, is given in a special section. The last chapter of the book contains a list of organizations dealing with studies of the Kuybyshev Reservoir and personal data on the contributors.

The manual will undoubtedly be of great interest and will be useful for a wide range of ecologists, specialists working in scientific research institutes studying inland natural and man-made waterbodies, as well as for specialists in environmental conservation. 